\title{
On the Development and Mode of E-commerce of Agricultural Products in Gansu Province
}

\author{
Haiying $\mathrm{Ma}^{1, \mathrm{a}^{*}}$ and Liqiong Yang ${ }^{2, \mathrm{~b}}$ \\ ${ }^{1,2}$ Provincial Key Laboratory of E-commerce of Ethnic Information \& School of Economics, \\ Northwest Minzu University, Lanzhou (730124), P.R.China \\ alxmahaiying8888@163.com, b1123002683@qq.com
}

Keywords: E-commerce; Agricultural products; Development and Mode; Gansu

\begin{abstract}
The e-commerce of agricultural products in the country to create a background of Internet plus, a new circulation mode of agricultural products conform to the trend of the development of. Based on the current situation of the development of agricultural products in Gansu province e-commerce as the breakthrough point, analyzes the existing network infrastructure in rural areas, agricultural e-commerce professional personnel, logistics, agricultural product standardization, branding, online payment system problems, put forward rural government enterprise, farmers or agricultural enterprises and intermediary organizations enterprise of agricultural products, agricultural products, online supermarket enterprises self built website four for Gansu Province agricultural products e-commerce model.
\end{abstract}

\section{Introduction}

Gansu province is a major agricultural province in China, and the output of many agricultural products is among the highest in the country. However, because the agricultural production dispersion, poor circulation, production project layout unreasonable, causes the agricultural product stage, seasonal, local excess, sales difficulties, seriously restricting the development of the rural economy. Developing e-commerce of agricultural products not only can solve the problems of poor circulation of agricultural products and timely information of agricultural products in rural areas of Gansu Province, but also help to raise the income level of farmers in the province.

\section{The current situation of e-commerce of agricultural products in Gansu Province}

Production Status of Agricultural Products in Gansu Province. Gansu is located in the upper reaches of the Yellow River, east of Shaanxi, south of Ba Shu and Qinghai, west of Xinjiang, north of Inner Mongolia and Ningxia. The province's 51 million 129 thousand and 300 acres of arable land, dry land more than $70 \%$, water is less than $1 / 3$ as a typical mountainous plateau area. According to statistics, in 2014, the total output value of agriculture, forestry, animal husbandry and fishery in Gansu was mainly created by agriculture and animal husbandry. Gansu has a long history of agricultural cultivation and many varieties of biological resources. Mainly wheat, barley and maize, millet, sorghum, millet, beans, potatoes, flax and other crops and oilseeds, cotton, pepper, lily, edible fungus, herbs, fruits, vegetables, melons, hops, hemp, tobacco and other crops. 65 animal species, including horses, West Shandan cashmere goat, Tianzhu white yak, Jingyuan Tan Sheep Varieties in the country has a high visibility, Tibetan sheep, sheep, beef cattle, Zaosheng cattle consumption, Walter lean pigs and other varieties are the main varieties of animal husbandry in Gansu. In 2014, the total grain yield of Gansu province was 11 million 586 thousand and 500 tons, of which 2 million 716 thousand tons of wheat, 5 million 645 thousand tons of corn, beans, potato 362 thousand tons 2 million 379 thousand tons; economic crops in 724 thousand and 200 tons of oil, 64 thousand and 700 tons of cotton, 274 thousand and 200 tons, 9 thousand and 900 tons of sugar beet leaves, herbs 993 thousand and 700 tons, 3 thousand and 300 tons of vegetables, hemp kind of 17 million 51 thousand and 900 tons, 4 million 252 thousand and 300 tons of fruit; Gansu Province in 2014 a total of 59 thousand and 200 cubic meters of 
tree felling, updating the forest area of 214 thousand and 20 hectares, Tung seed production of 268.35 tons, 713.57 tons of meat yield; yield 997 thousand and 300 tons, including 547 thousand and 400 tons of pork, beef and mutton, 193 thousand and 400 tons and 193 thousand and 100 tons.

In addition, in Gansu there is a variety of agricultural cultivation, potato, cotton, vegetables, fruits, melons, hops, seed, herbs, broad bean, lily, tobacco, grass products, animal husbandry have formed local advantage products; seed yield of hybrid maize, potato, beans, with an annual output of fresh potato output black seeds, brewing raw materials output ranked first in the country; the planting area of 255 thousand and 790 hectares acres, yield 993 thousand and 700 tons, there are more than 50\% Chinese angelica, Codonopsis, Radix Hedysari, astragalus, licorice and other herbs produced in Gansu, the Chinese angelica root accounted for the total yield of $95 \%$.

At present, Gansu province has designated the Ministry of agriculture of agricultural products wholesale market 30, 50 leading enterprises, the focus of the market in 100, the number of farmers' professional cooperatives has exceeded 1 million, the agency up to 590 thousand farmers, accounting for the total number of $14.2 \%$ households in Gansu Province, more than $50 \%$ of the total members of the cooperative family income from cooperatives. Than not far into the farmers' income is generally higher than $20 \%$, farmers' professional cooperatives in rural areas of Gansu province has become the important subject of modern agricultural management.

Development Status of E-commerce of Agricultural Products in Gansu Province. Gansu has established an information collection and release platform covering 14 cities (prefectures) and 87 counties (cities), and 4461 village level information service points. "Statistical report" thirty-seventh Chinese Internet development statistics show that by the end of 2015, Gansu Province, 10 million 50 thousand Internet users, the Internet penetration rate of $38.8 \%$, the growth rate of Internet users reached $5.7 \%$, Internet penetration rate in the country ranked 28 . Information services, the use of the Internet, television, mobile phones and other media for the villagers to publish agricultural products information, technical advice and guidance and industrial development services. But from the ownership of Gansu Province in 2014, the average per 100 rural household TV, fixed telephone, mobile phone and computer network infrastructure construction, the province of e-commerce of agricultural products also exist.

In recent years, Gansu province science and education development momentum is good, by the end of 2014, the opening of 38 colleges and universities in the province, 6 adult higher school, the other 39 private higher education institutions, 91 secondary vocational schools, 28 adult secondary specialized schools, 125 occupation high school, 81 technical schools, the annual graduate students up to 118697 people. According to the basic data of the sixth census, the total population of Gansu is 25 million 575 thousand and 300 people, including 9 million 236 thousand and 600 urban population and 16 million 338 thousand and 700 rural population. The number of illiterates is at most 2 million 222 thousand and 200, 7520 are college and above, 12686 are in high schools and secondary schools, 31213 are in junior high schools and 32504 are in primary schools. At present, the overall education situation in Gansu needs further promotion.

\section{The Existing Problems of E-commerce Development of Agricultural Products in Gansu}

Rural Network Infrastructure Lags Behind. Agricultural products e-commerce in the information release, inquiries, online sales, online payment and other links are inseparable from the internet. Statistics show that China's Internet penetration rate of $50.3 \%$, that is, the country's $1 / 2$ population in the network coverage. But only $28.4 \%$ of rural residents can use the Internet, and the level of rural Internet development lags far behind that of cities and towns. Excessive information acquisition costs also lead to information can not be one of the reasons for home. The vast rural population in Gansu can access the Internet through mobile phones as an information tool, but because of excessive information costs, the rate of mobile access to the Internet is low. Through computer access to the Internet for the vast majority of rural residents in Gansu is not feasible, the cost of buying a computer, plus the broadband installation fee and broadband usage fees, villagers use the Internet at least once a year to spend 3600 Yuan, and the 
per capita net income of farmers in the province in 2015 was 5736 Yuan, the cost is that they cannot bear.

Agricultural Products, E-commerce, Specialization, Lack of Qualified Personnel. In recent years, e-commerce has been rapid development, the demand for specialized talents is larger. "2015 China's e-commerce talent survey report" shows that $75 \%$ of the electricity supplier enterprises exist shortage of talent phenomenon. We can see from Figure 3, in the selection of the 305 companies surveyed, 44\% of the enterprises need the electricity supplier operations personnel, personnel of the $18 \%$ enterprises need technology, $22 \%$ of the enterprises need to promote sales personnel, $5 \%$ of the enterprises need supply chain management talents, enterprises need fully $11 \%$ of senior personnel. Visible, China's electricity supplier operators still have a big gap. Electronic commerce of agricultural products requires not only to be familiar with the methods and methods adopted in the process of agricultural products management, but also to be proficient in the combination of network technology and e-commerce technology.

Lack of Logistics Distribution System of Agricultural Products. First of all, as a special kind of commodity, agricultural products are easy to rot in storage, transportation and sale, and need to establish a perfect logistics and distribution system. The production of agricultural products has seasonal and cyclical characteristics, it is not easy to store, to ensure quality preservation, preservation must be frozen, cold chain logistics is the key. Secondly, the rural transportation infrastructure needs to be further improved. Rural road is an important factor to ensure the circulation of agricultural products in Gansu. Although rural areas are constantly building roads, most of them are mountainous areas, and there are still some administrative villages which are not open to traffic. Third, the bottleneck of the application of the third party logistics. At present, the European use of third party logistics service ratio was 76\%, 58\% in the United States, Japan $80 \%$, China is only $11 \%$, but there are many problems, such as equipment system backward, low working efficiency, high error rate, and express company does not close, backward mode of operation.

Poor Standardization and Brand of Agricultural Products. Gansu province has to construct the system of standardization of agricultural products, but there are still some problems: one is the quality and safety inspection system of agricultural products has been completed, but not perfect, the layout is not reasonable, the responsibility is not clear, insufficiency and low efficiency of operation; the two is the quality and safety of agricultural products traceability system is not perfect, can not achieve full coverage of agricultural product quality and safety traceability management; three is the agricultural product quality safety supervision of law enforcement is not enough, the regulation is not in place, the awareness of farmers is not high, the quality standard of agricultural products is not up to the requirements; four is the standardized production of farmers' awareness is not enough, do not understand the implementation of standardized production function. Affected by traditional agricultural production methods and methods, farmers blindly pursue high yield and excessive use of fertilizers and pesticides, which are not carried out according to standards.

The Payment System imperfection. At present, Gansu Province agricultural products e-commerce online payment to the commercial banks to issue bank cards as a means of payment in the transaction of agricultural enterprises, agricultural enterprises, intermediary organizations and farmers, and farmers is closely related to financial institutions only agricultural businesses, almost no branches of other banks. This hinders the rural area network payment to a certain extent. Due to the use of online banking for electronic payment, the user's security awareness is weak, there are user accounts, password theft occurred. Most farmers in Gansu refuse to use online payment when they worry about the security of bank cards in online payment.

\section{Model of E-commerce of Agricultural Products}

Farmer-Government-Enterprise. In view of the shortage of agricultural products in Gansu Province, business professionals farmers separate production and scattered, low education level of the farmers, in the electronic commerce mode of understanding the actual situation is not sufficient, consider the development of a third party transaction market mode by the government as an intermediary platform type. The agricultural e-commerce model, which is actively participated and directed by the government, 
is the most suitable for the current situation in Gansu province. The government as an intermediary, can give local farmers timely release of a large number of agriculture related information, such as news, the price of agricultural products, livestock and poultry breeding technology, market supply and demand of agricultural products and farmers training information.

This model has played a very good guiding role in promoting the development of e-commerce of agricultural products, because the government as an intermediary, both farmers and enterprises both have higher authority and credibility. For farmers, to guide the production according to the market demand information available to the government, but also the order type production with the power of government, so as to ensure that farmers produce their own products to sell; to the enterprise, timely feedback to the government departments of agricultural products demand information, and then by the government departments.

Agriculture Related Enterprises-intermediary Organizations-Enterprise Model. This third party transaction platform built by intermediary organizations has a high matching capacity. At present, the larger of the third party trading platform is Alibaba, HC, Chinese manufacturing network, the platform has the transaction process fair, standardized, safe and efficient trading platform, the characteristics of high professional level, both parties can release supply and demand information, inquiry, negotiation, contract, payment, delivery of products using the platform. This model effectively solves the problems of unsmooth trading, asymmetric information, unfair trading, non-standard and unscientific problems existing in traditional commercial activities. Gansu province area of 51 million 129 thousand and 300 acres of arable land, there are a lot of corn, bean, fruits and vegetables, barley beer, dehydrated vegetables, herbs, lily, black fungus and other agricultural products need to be sold each year, but because farmers scattered, many buyers take home purchase, farmers themselves to the traditional sales model one or two wholesale market sales or retail surrounding farmers into the city, seriously hindered the development of agricultural modernization process of Gansu province. The model provides farmers with new marketing channels for agricultural products sales information and agricultural products online transactions, and also provides services to the specialized farmers who grow special agricultural products.

The Mode of Agricultural Products Online Supermarket. Online shopping has the characteristics of time and space, convenient, time-saving, convenient and low cost. It has become an important part of the daily life of consumers. The traditional agricultural products and the Internet industry combined, designed with the mode of agricultural products online supermarket, the actual situation in Gansu Province, can save a lot of unnecessary middlemen, reduce operation cost, realize the products of high quality and low price, the common benefit of farmers and consumers.

The model is a B2C model, and its core is the production, marketing organic combination. First of all, meat and vegetables, fruits, eggs, milk, and other agriculture related enterprises to cooperate with logistics enterprises or agricultural cooperatives, orders, signed a purchase contract and guide farmers to carry out standardized production, farm. Secondly, agricultural enterprises or agricultural cooperatives set up agricultural products supermarket store in the community, agricultural cooperatives of agricultural products logistics distribution planning area, through the form of direct selling agricultural products for city residents. At present, in Lanzhou City, the community has opened more than relying on agricultural enterprises or farmers' professional cooperatives, in the surrounding areas as the supermarket store agricultural products mainly supply of agricultural products, to bring great convenience to city residents.

Agricultural Products-Leading Enterprises Built Characteristic Website. Leading enterprises of agricultural products with its abundant capital, professional talents are available, with modern information technology and other advantages, in the process of implementing e-business well play a leading role, promote the development of agricultural e-commerce. With the government or intermediary organizations to build third party trading platform, leading enterprises of agricultural products according to the characteristics of self built website of agricultural industry, the enterprise's own characteristics, the connotation of enterprise culture, corporate image, brand of agricultural products to maximize the show, to attract readers to browse and buy products. The establishment of this web site to the leading enterprises of agricultural products and industries, is conducive to the expansion 
of the product range of the publicity, to promote agricultural development, implementation and customer communication and exchange of information, and promote the development of E-commerce of agricultural products. But as of now, Gansu Province agricultural website is relatively small, agricultural products leading enterprises self built site number is less, only a small number of enterprise website do phase

\section{Conclusions}

For the better, such as Gansu Province, Dunhuang seed industry Limited by Share Ltd, Gansu Teng Sheng Agricultural Group Limited company website, but there are also beautiful design, the website function is more simple, content interactive, practicality is not strong enough, the lack of professionals and other issues, therefore, the development mode is the leading enterprises and all sectors of society efforts to get better. At the same time, agricultural enterprises or agricultural cooperative organizations can be the statistics of sales of various types of agricultural products from the online supermarket, analysis of the relationship between the demand, guiding farmers to focus in the production process in the next allocation of the number of agricultural products, to a certain extent alleviated the problem of farmers' agricultural products sales are sluggish.

\section{Acknowledgements}

This work was supported by the Key Laboratory of E-commerce of Ethnic information in Gansu Provincial and Comprehensive experimental teaching center in Economics(Grant No. 2016XJSYJXSF2X-01-10019109) and by Special Funds for Undergraduate Teaching Reform by Central University of Northwest Minzu University (Grant No:10019153 ).

\section{References}

[1] Statistics Bureau of Gansu province. Yearbook of Gansu development. Beijing: China Statistics Press, 2015.

[2] China E-Business Research Center. Survey of Chinese e-commerce talents (2015).

[3] Hu Qiangguo, Enterprise economic benefit analytic hierarchy process, 3(1994)40-48.

[4] Hong Tao, Li Chunxiao, Study on the development of e-commerce model of agricultural products in China, commercial age, 16 (2014) 51-60.

[5] Hong Tao, Zhang Chuanlin, Study on the development of e-commerce model of agricultural products in China, Commercial Age, 17 (2014)76-82.

[6] He Zhihan, Discussion on the reform and management . enterprises in Hubei Province agricultural products e-commerce model, 8 (2016) 61-69.

[7] Sun Lei, Research on innovation of logistics management model of agricultural products in Hefei . Journal of Hunan City University, 2 (2016) 186-192.

[8] Lin Yin, Optimization of e-commerce distribution model for fresh agricultural products. e-commerce, 5 (2016)7-13. 